\title{
Downgrading by improvement?
}

\author{
The situation of Moroccan actors in trekking-tourism in the Atlas mountains
}

\begin{abstract}
For many actors in developing countries the integration into a global value chain is the only possibility to gain access to western markets. The Moroccan actors quickly adapted to international standards and made the Atlas Mountains a well known destination for trekkers. This process of organizational learning however did not stick with the actors inside the chain, it spread over to other actors in the region and this at first seemed to be a desirable effect as it provoked regional development. But soon it turned out that it also increased competition and hence weakened the position of the Moroccan actors compared with the European lead firms who where well protected by efficient barriers to their activities. The paper argues that organizational learning does not necessarily lead to a process of upgrading when the market is restricted and no sufficient barriers to protect this knowledge are possible. Knowledge then will become a ubiquitous asset and the achieved enhancement on the regional scale will lead to entrepreneurial losses for the single actor. Keywords: global value chains, tourism, regional development, Morocco.
\end{abstract}

\section{Introduction}

International tourism is one of the most important and fastest growing economic branches worldwide. After years of fierce discussions between modernists and adopters of the dependency-theory about the role of tourism in developing countries it seems to be clear that the effects and importance of tourism cannot be treated in a simple way as all positive or negative but have to be seen in the very individual context of each country and region. Tourism, at least in many cases, is nowadays considered to be a potentially useful instrument for regional development in developing countries, for some of them even the only possibility to acquire foreign exchange, but without the absolute claim of prosperity and development that prevailed in the high period of modernism (see e.g. DiAz BENAVIDES 2002; REID 2003). Especially the role of so-called alternative or soft forms of tourism, such as ecotourism, trekking and hiking or artistic activities which have emerged during the last two decades, seem to be interesting in this respect as they don't require huge equity investments in tourism infrastructure. In- stead they often promote intact unspoilt nature and authentic people in remote areas, all of which seems to suit ideally to what developing countries have to offer. But there is no smoke without fire and even these forms of tourism cannot take place without having impact on the visiting region. There is already quite a huge body of literature existing dealing with the effects of soft tourism and in the worst case we'll find that the only respect in which they are "soft" is that there are only poor economic gains for the local people (MÄDER 1991).

Especially in the context of economic development issues analysis shouldn't be restricted on quantitative information about how much money stays in a particular tourism region. Studies on global commodity production have revealed the importance of organizational aspects and the question of where power is located when economic actors wish to shape their competitive assets in the global economy. In this regard value chain approaches gain special interest as they provide an insight in how global economic relations are institutionalized and governed. Value chain analysis describes the full range of 
activities necessary for the fabrication of goods and commodities and show how these are related and coordinated. It thereby explains the repartition of economic benefits related to these activities and underlines the fact that these benefits underlie a changing dynamic process (KAPLINSKY/ MORRIS 2000). As in tourism different activities made from different actors in different places are brought together to form a final "product" which is the organized holiday tour, transferring the value chain idea from industrial production to tourism seems to be justified (Go/APPELMAN 2001, 184). The main questions in this context are how actors are able to gain access to a particular chain, how they can turn their entry to a permanent integration in the chain activities, which economic consequences do result out of this integration and how they can influence these economic outcomes. Value chain studies underline the fact that for many actors, especially those from developing countries, access to globally linked activities poses a sine qua non to enter global markets and to improve their situation by acquiring experience and knowledge about global standards and procedures which then allows them to upgrade their range of activities (GERREFI/MEMODOVIC 2003; HUMPHREY 2003).

This paper comprises of six sections: The first section provides an introductory overview of the evolution of trekking and adventure tourism in the Moroccan Mountains and its actors. In the second section is shown how the single activities are linked and governed by the European tour operators who can be identified as the lead firms in the in the Mountain tourism value chain. In the third section we will then have a closer look at the entry barriers to the tour operators' activities that hinder Moroccan actors to enter this niche. Then we go on to discuss the consequences of the asymmetric proportion of power and the alternative possibilities for the Moroccan actors to upgrade their position in the next two sections. In the concluding section I would like to build upon these findings and ask about the consequences on the regional and entrepreneurial scale. My hypothesis in the case of the Moroccan trekking business is that experience, knowledge-spread and acquainted professionalism throughout the firms and actors in the region do enable a regional upgrading. But upgrading on the regional scale may lead to the converse effect on the firm level and thus, in the long run, hinders a further regional economic development as long as there is no sufficient means of power to shape the ways in which transactions are institutionalized and direct market access is possible. The findings of this paper are based on qualitative interviews which have been conducted during the period 2002-2005 with all of the noteworthy Moroccan travel agencies, at the time 15 travel agencies dominated the Moroccan trekking business, as well as with all tour-operators in France, the UK and Germany offering trekking in the important destinations of the Jbel Toubkal, the Ait Bougmez and the M'goun Valley and in the Jbel Saghro. Altogether 20 tour operators have been interviewed. Finally 32 qualitative interviews with Moroccan mountain guides have been made during the study.

\section{The evolution of mountain tourism in Morocco}

The origins of tourism in the Moroccan mountains dates back to the time of the French protectorate when European residents visited the mountainous regions nearby the bigger cities like Fes, Meknes or Marrakech for recreation or hiking. Already in 1923 a section of the French Alpine Club was formed in Casablanca and until the mid-nineteen thirties all the higher summits in Morocco had been climbed. After the French had left the country, Mountaintourism fell almost entirely into oblivion and it was not before the second half of the 1970s that Morocco regained attraction as a destination for trekking and hiking. At that time, trekking tours resembled more an expedition than a holiday tour. The total number of tours remained very small and they were entirely carried out only by a few specialized tour operators only. The role of Moroccan actors at that time was restricted to carrying the baggage or showing the way.

This changed fundamentally within 1980s when the Moroccan state discovered the tourism potential of the Atlas mountains and decided to promote tourism development there. In association with the French Alpine $C l u b$ a training centre was founded in Tabant in the Central High Atlas to train Moroccans to be mountain guides. Also the local people were encouraged and supported by a financial aid program to invest in modest buildings or extentsions to be used as guesthouses or small 
restaurants in order to build up the necessary infrastructure and let them participate in tourism. These small private pensions, called gîte d'etape have since been promoted through the common label GTAM, which means grande traversée des Atlas Marocains (see AIT HAMZA/ Popp 2000). At the same time the first Moroccan travel agencies appeared to fulfill the function of an incoming agency for the European tour operators. In the following they became responsible not only for organization, logistics and dealing with local actors but also for issues of conception and tour planning. It is precisely at this point that trekking in Morocco experienced a real boom during the late 1980s till the second half 1990s. The Moroccan actors allowed the tour operators to externalize most of the activities inside the country and thus to reduce the costs of a trekking tour that otherwise would have been much higher. Because of the small number of tours no economies of scale were to realize. This possibility of cost reducing through externalization brought the prices down to an internationally competitive level and made Moroccan destinations interesting for a growing number of international tour operators. Consequently these concentrated on marketing and distribution functions as their core competencies while the organization and the conception of the tours were left to the national agencies and carried out by local actors in the destinations.

\section{Who governs - and why?}

After the brief description of the involved actors and activities in the Moroccan trekking business, the question rises who is able to gain power out of its activities and why. Power is nothing to exist by itself; the potential to exercise power is always based upon a certain resource. In value chain concepts the access to key activities and - even more important - the possibility to defend and block this access against competitors is the basis upon which power is built up. On first sight it seems as if the travel agencies in Morocco are holding all cards in the game, for they have the equipment and the knowledge to plan and perform a trekking tour. But in reality it's the tour operators who decide which tour they will offer, set the conditions for the agreements and fix the prices. So what is the asset that puts them into such a powerful position and leaves the Moroccan players restricted to a relative weak po- sition? To answer this question we have to take a closer look on the demand-side of trekkingtourism. Trekking, as a form of alternative or soft tourism, combines in a way activity, adventure and responsibility for the nature and the people visited. What trekkers seek (and tour-operators promise) is beyond a normal holiday, it is the deliberate choice to travel under sometimes very modest and physically exhausting conditions into remote areas to have an intensive holiday experience. To satisfy clients it therefore takes more than just good weather, a white beach and good hotels. Defining quality in this niche is much more complex and sophisticated (see YUNIS 2002). What makes things even more complicated is the fact, that services in tourism must be counted among the so-called experience goods, that means, there is no way to measure the quality of a tour before it has taken place. And as exante proofing is not possible, it is decisive for a tour-operator to give serious evidence about its business efficiency and its proclaimed quality demand in order to convince a potential client and make him trust his offer (see also COOPER/ WAHAB 2001, 325). We have thus to find out first which elements form the quality of a trekking tour in detail, and then, how touroperators seek to make their services apparent to the tourist.

The first point in this context will be called "calculated adventure aspect". Trekking tours often lead to remote and hardly accessible areas, sometimes in high altitudes (even though most of them do not require alpine skills or special equipment) and under extreme climate conditions. Food sometimes differs a lot from what the average European stomach is used to. When it comes to contact with local people it is unlikely that tourists can talk to them in their mother-tongue or sometimes even to understand gestures and behavior in the right way. In emergencies medical facilities are often far away from the visited place. This is where the tourist depends on the knowledge and experience of the tour-operators staff. Tour-operators emphasize the experience and education of their staff-members. They may for example refer to university degrees (e.g. in biology, ethnology, geography) as well as to training courses in mountaineering/professional tour guiding or security all combined with a longtime experience. To give evidence for their abilities, almost every tour-operator has one or several real expeditions in the program, like 
climbing the highest peaks in the Everest region or crossing the Antarctic. Persons working for a specialist tour-operator are shown not just as simple employees in a tourism enterprise, but as real experts and enthusiasts of trekking and adventure who made their passion a job. The whole firm is presented like a club the client can join and be part of. The advertising aims to show that trekking tours are exotic, adventurous, thrilling and sometimes even (a little bit) dangerous, but without serious risk if you join the club and rely upon experts to advise you and take care of everything.

The second point is the "good consciousness aspect". Trekking and adventure tours are not just ordinary holiday tours. And specialist touroperators underline in their catalogues the fact, that they are no ordinary holiday brokers. Trekking is marketed as a form of alternative tourism, it is soft and responsible. And trekkers give a lot of importance to this. Interviews made with trekkers in the Atlas Mountains showed, that most of them judge tourism in developing countries very critical, whereas they rate the tour they have chosen to comply with the demands of responsible tourism (see LESSMEISTER 2005). The tour-operators respond perfectly to the demands of alternative tourism when they describe that their tours do not have any negative ecological impacts (traveling without leaving any traces), do respect nature and even support the local people. Here too, they can give evidence for their claim. The most common way to do this is by supporting non governmental organizations (NGO) who work in the mentioned fields. There is no touroperator who is not involved in one way or another in some NGO activities, most of them dealing with issues of nature and wildlife conservation (e.g. World Wildlife Fund, Mountain Wilderness) but also with development issues (e.g. Tourism for Development) or responsible tourism (Charte éthique du voyageur). This again provides the trekker with the desired feeling of not just being an ordinary tourist but a responsible traveler. Following the rules of responsible tourism and supporting NGOs in their activities make holidays in developing countries a pleasure without a bad conscience.

The third aspect is dealing with insurance and consumer production, here called the "money back aspect". Even though the tour-operators may perform to a high quality level, something may go wrong and clients might be unsatisfied and complain, especially when services are concerned which are not in the tour-operators hands (like flight services or accommodation). For this reason it takes the tour-operators several institutions to make obvious that there will be no, at least no financial risk for the tourist. Again, institutions and organizations play an important role. In this context we also have to mention the role of insurance. Not only do tour-operators take care for assuring their clients when offering a full package tour. They also have to insure themselves against compensation claims and make hereby evident, that in the worst case they are financially able to compensate unsatisfactory performance. The second point is membership in an organization that guarantees consumer protection like the International Air Transportation Association (IATA) or the Air Travel Organisers' Licensing (ATOL) protection scheme for flights and air holidays. These organizations survey and certificate the performance of their members. Finally, already a written contract with an authorized company itself represents institutionalized security, as it gives the client the possibility to go to court and take legal action.

Resuming these three aspects we can say, that a trekker who intends to go on a holiday with a European tour-operator is provided with a variety of information to check the operator and his product. He can thereby minimize the risk to choose wrongly and waste money or even get into serious danger and has the possibility to get financial compensation in case of any shortcomings. The tour operators' reputation thus results from a combination of the image they create and the way they institutionalize this image and guarantee quality and professionalism. This enables the consumer to minimize risks - while optimizing satisfaction. The possibility to institutionalize their claim for quality opens the door for the international tour operators to the packaged trekking- and adventure market and enables them to gain direct access to the consumer.

\section{Barriers to entry for the Moroccan tourism actors}

It was shown how European tour-operators manage to have access to the market. But what happens on the other side? Why are Moroccan 
actors excluded from direct access to the European market? Again it's not just for one simple reason. First, the most obvious factor is the realm of activity that results out of repartition of the work in the trekking value chain. While the European tour-operators are present in almost all important destinations across the world, Moroccan actors are limited to their own country or even only to some particular regions in Morocco. As a consequence, the tour-operators work together with one incoming agency in each country whereas the incoming agencies must seek to establish many relations to foreign partners. As each of these partners is contributing only a (sometimes very small) share to the total number of tours it must be in the strategy of each Moroccan agency to establish as many relations in as many markets as possible. Up to now, market access is only possible via the European partners, who sell and promote the products in their home countries. For a Moroccan player, direct market access would therefore mean that he has to be present not only in one, but in several emitting countries. This would firstly require special knowledge about appropriate marketing techniques for every single market (KeEGAN, W. 2002, 19). It would, secondly, take an immense financial effort to finance advertising and public relations and it would furthermore require an experienced and professional office staff for direct consumer contact. Whereas at present they have to deal with "ready made" groups of tourists sent by their partners in Europe, they would then have to inform and advise potential clients. This in turn would require a spatial location in close proximity to the clients (e.g. offices in the bigger cities) if they don't want to rely on phone or internet only (which makes it even more difficult for firms to provide consumer trust). And even when working via phone and internet only, a well-educated staff is needed to handle inquiries in different languages (let alone the different mentalities). Taking over the tour-operators activities would consequently entail an immense effort in financial, organizational and personal aspects. And to stay present in the emitting countries there are also political and administrative obstacles to overcome, like residence or labour permits and visas.

But even if Moroccan actors (theoretically) could cope with all of this and manage to enter the European market, they still would lack the institutionalized ways to gain consumer trust like described before for the European tour-op- erators. Moroccan actors are only seldom involved in NGO activities and if they do so, this will not attract much attention to European trekkers, as long as there is no appropriate way to promote it. Concerning consumer protection, no comparable organizations or agreements to those in Europe exist in Morocco. And of course the prospect to defend one's right before a Moroccan court doesn't contribute very much to create consumer trust in Moroccan offers. And finally Moroccans do not only have to establish relations to consumers, but also to all supplementing actors like insurance companies, publishers, air companies 1 . Access to European markets would thus premise entering the corresponding institutions and networks first.

\section{Structurally one-sided dependency}

So far it was shown how the tour-operators in Europe gain power out of direct market access and how barriers prevent the Moroccan players from entering their position in the trekking chain. But after the discussion of barriers and market access one may ask about the problems of this international repartition of work where one side is selling and the other one's producing. The Moroccan actors do depend on European operators because they offer the only possibility to enter European markets. But do not the European tour-operators as well depend on their Moroccan partners who actually do all of the performance in Morocco? Theoretically they may carry out everything on their own, but using European employees on every stage of the chain would of course raise the costs to a non-competitive level. Taking this into consideration, a mutual state of dependence, with the Moroccans acting as "producers" in a quite powerful position could be expected. In reality this is only partly true. To explain why this is the case and what is problematic about it, we once more have to take a closer look on the evolution of the trekking tourism in Morocco.

When trekking started on a noteworthy scale in the mid 1980 s, only a handful of incoming agencies in Morocco existed to cover the whole market. The situation changed radically when the first instructed guides de montagne (mountain guides) left the training facilities in Tabant. From that time on, every year 30 to 40 new professional actors entered the race. With the Moroccans gaining experience and becom- 
ing more and more professional, trekking destinations in Morocco became interesting for an increasing number of tour-operators in search of suitable partners, and this, in consequence, made more and more Moroccans enter the trekking business. In the beginning the Moroccan players held a competitive advantage as they had the knowledge about tour-programs; they knew the terrain and the places to go and they could establish personal contacts to local actors or even formed part of some social networks (often through family ties) in the respective destination areas. But it turned out, that they were not able to keep these advantages and very soon the knowledge about tour-programs and organization changed from an innovative asset into an open secret, especially because the number of highly demanded tour-offers concentrated only in a few regions, mostly in the Jbel Toubkal region and in the valley of Ait Bougmez. It can be stated that most of the touroffers in Morocco resemble each other in content and course and follow more or less the same itineraries. Regional knowledge soon lost its role as a barrier to enter the position of the incoming agencies. The other barrier to this activity used to be reputation. Tour-operators usually prefer to work with reliable partners. As services cannot be future proofed, experience made during the cooperation has been for a long time the only possibility for rating the associate. Based upon this experience it takes the tour-operators just a bit of "fine-tuning" to lead the partner's performance into the desired way. The intention to keep a reliable partner may explain why co-operations in the Trekking Tourism usually used to be relative long lasting ones (some co-operations exist since the very beginning in the mid-eighties).

But this situation is about to change too. Since the mid 1990s a second generation of incoming agencies has come to existence. These firms were opened up mainly by former mountain guides, who had worked before for one of the established agencies. Even though they have only been in existence a few years, their owners can look back on years of experience and know very well what European tour-operators give importance to and, thus, about how to stay in the game. Even capital of $20,000 €$ brought in, demanded by the Moroccan state, turned out to be quite an inefficient barrier to protect the pioneers among the national agencies. From only four agencies in 1986 their number today has increased to 15 who hold their ground in the trekking and adventure holiday business. Thus, competition also has increased tremendously because similar tour-offers and a comparative great number of experienced agencies, all operating more or less on the same quality level, do minimize the risk of high transaction costs for tour-operators intending to change their associate partners in Morocco. This weakens the position of the Moroccan agencies and a growing number of tour-operators breaking off their former co-operation or using the possibility to do so for cutting down the prices can be observed. At the same time some tour operators establish their own incoming agencies as a branch office. And here again there is the somehow paradox situation that in particular those agencies seem to be affected from exclusion who did good business before: because the internalization of the agencies' function for the tour operator is only cost-efficient when he can sell about 2000 2500 tours per year in the given destination. Finally we have to mention those tour operators who work directly with mountain guides, without passing by a Moroccan agency. This is, according to Moroccan law, an illegal form of operation, as the legal acts Loi N 31-96 portant statut des agences de voyages and $N 30-96$ portant statut des accompagnateurs de tourisme, des guides de tourisme et des guides de montagne clearly define the responsibilities of the mentioned actors and restrict the guides to guidance in the trekking area only, prohibiting him any kind of organization. But in reality the official authorities (brigade touristique) have no efficient means to control and supervise all action in the trekking business and this again reveals the existing barriers as insufficient to protect the position of the agencies.

The asymmetric distribution of power and dependency also comes to play an important role under altering economic conditions. Not only is competition among the Moroccan actors getting increasingly fiercer, but also between European tour operators competition is getting harder. In recent years a change in the consumer behaviour of tourists in Morocco can be stated. Roughly spoken, the general trend goes towards shorter and cheaper holiday trips (PAUCHANT 1995). Consequently, many tour operators have to reduce the final prices for their tour offers to stay competitive. But their position as the most powerful actor in the chain nevertheless allows them to keep a fixed share of the final price. In consequence, if 
money has to be saved in the overall calculation, financial cuts are more likely to be done in the fields of the Moroccan actors which result in sinking shares for them. That this is not just a theoretical thought is shown in Tab. 1. In fact, the final prices for trekking tours in Morocco have generally fallen in recent years and sunken shares were stated (to different extents) by all of the interviewed travel agencies (LESSMEISTER 2005). The Moroccan agencies find themselves in a very unpleasant situation: They depend on their European partners be- cause these provide them with access to the Western markets. This dependence is onesided because the tour operators are the only ones in the chain who have direct access to the consumer market; this brings them into a gatekeeper position (IOANNIDES/ DEBBAGE 1998) which the Moroccans haven't been able to enter yet. This structural asymmetry of power proved to be an efficient barrier to prevent the Moroccan players from direct consumer access. On the other side these have not managed to build up efficient barriers to protect their

Tab. 1: Change in the final prices between winter season 2001/2002 and 2004/2005 for the most demanded destinations

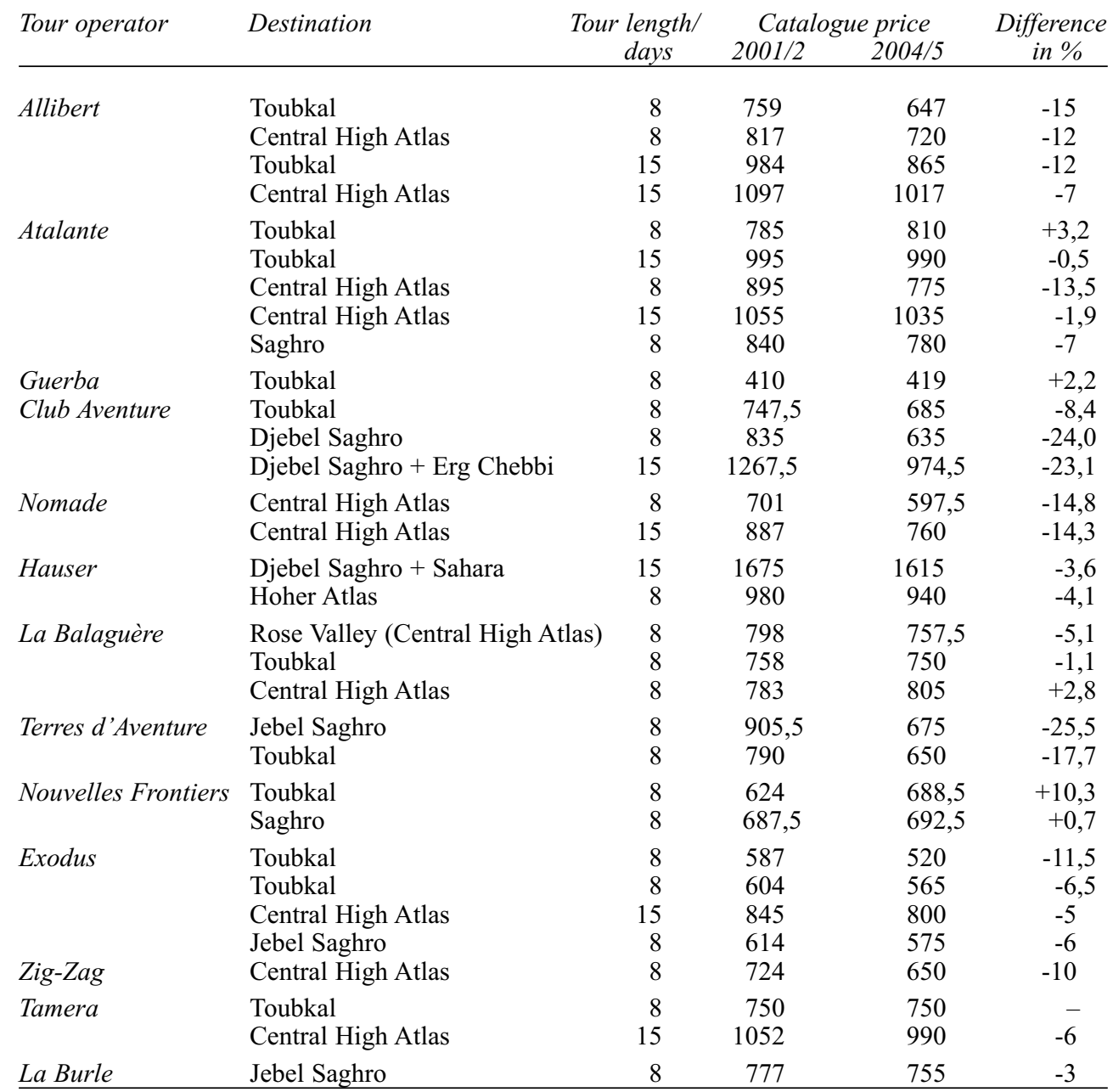


own position. The integration in a global value chain made them quickly learn and adapt to the required international standards and rules, so that at present almost all nameable agencies do operate on a similar level and none of them is able to use this as a special asset to increase competitive advantage.

\section{Individual tourists - a real opportunity?}

One may object now, that the so far presented findings do refer to packaged tours only and that besides these some people prefer to plan a holiday on their own instead of purchasing an organized tour. The question is now, whether there is a market for individual trekkers and if so, for whom and to what extend it may hold an opportunity. When talking about individual tourists and organized packaged tours it must be said first, that there is no official data available about the total of trekkers visiting the Atlas mountains, let alone the percentage of individual and organized travellers. Aggregated statistical data is only available on the national scale or for single provinces. Unfortunately their value is rather limited as several trekking destinations lie within more than one province. Furthermore the official statistics do not distinguish between different forms of tourism. Mountain and "classical" tourists appear in the same statistics without any possibility for differentiation. Besides, the data given is not always complete and reliable. Finally, especially on trekking tours the acquisition of arrivals and overnight stays in officially listed houses is not an adequate means to provide representative figures about tourism activities because many stays take place in tents. So we have to rely on [justified] estimations: BouJROUF (1995) e.g talks about 15,000 tourists per year for all destinations in the Moroccan mountains (which of course says nothing about the time they stay in the region). AIT HAMZA/ POPP (2000) found for 1996 already 5,300 guest arrivals only in the classified guest houses in the region of Azilal in the valley of Ait Bougmez. They estimate a total of approximately 30,000 tourists p.a. for all Moroccan mountains. This seems to be a realistic figure as it does conform to the average estimations of the questioned Moroccan travel agencies and mountain guides, talking of some 30,000 to 40,000 tourists. What seems to be more interesting in this context is the fact that, according to them,
$70-80 \%$ of the tourists arrive via a tour operator. This again is corresponding with our findings of a questionnaire done with 330 tourists in the Toubkal region and the Jebel Saghro where the proportion of organized tourists was $78 \%$ and $97 \%$ respectively. For the rest we have to differ between individual trekkers who come explicitly to do a mountain tour and those tourists who visit Morocco on a classic itinerary (imperial cities, Great South) and just wish to add one or a few days in the mountains. Mainly the latter we find in the Jebel Toubkal region, which is very close to Marrakech, easily accessible even with public transport and well-equipped with several guest houses and small restaurants, a well functioning agency to hire the services of a mountain guide and a variety of shops to buy food or any kind of trekking material. For most of the individual tourists, be it in the Toubkal or in some other region, the service of a guide is inevitable, because there are no reliable maps for any of the Atlas regions and also most of the local people don't speak any foreign language. But when in search of a guide, individual tourists see themselves confronted with the same problems as organized tourists going on a package tour. Even though many guides have discovered the internet as an appropriate means to promote their offers it is impossible to judge their quality before the tour. The internet hence holds a quite efficient way to minimize risks: Internet trekking platforms and chat rooms, where trekkers exchange about their experience with particular guides and give recommendations (including phone numbers or e-mail addresses of reliable guides or warnings when it is about bad experience). Another way for the guides to create trust is to pass their offer via a European mediator (often a friend or acquaintance made during a former trekking tour) who serves as a trusted third party when potential clients feel insecure about entrusting their holiday to an unknown Moroccan guide whose performance they cannot judge. A positive word of mouth recommendation is very efficient publicity, and being listed on a trekking websites or mentioned on an internet platforms enhance a guide's chance for success. The same is, of course true for traveller guides and handbooks. These medias serve for the individual tourist as the primary source of information and help to find orientation in the foreign country. They rely upon the given information, hence for the guides recommended herein this may be considered an in- 
stitution to create consumer trust.

Whereas the Moroccan travel agencies are facing severe difficulties to get direct consumer access on the packaged tour market, this seems to be easier for the Mountain Guides on the market for individual travellers. But despite this, the general situation for most of the Guides must not be seen as a very promising one. Like the incoming agencies they have to cope with the problem that there is simply too many of them competing for work. Each year about 40 new Guides finish their courses in the training-centre in Tabant and try to work in the trekking business. At present about 450 Guides compete for trekking tours, not included is the unknown number of non-official Guides. And by far not all of them manage to find employment at a travel agency while the share of individual tourists in the Atlas Mountains holds, as already mentioned, only a small proportion. All in all we can state an oversupply of labour which leads to a situation of fierce competition and increases the pressure to come down with the prices and work for less than the officially fixed wage. So again, the situation of the Moroccan guides show that improvement through skills and knowledge is only useful when there is at the same time the possibility to put up efficient barriers to prevent others to adopt these skills and enter the business.

\section{A hypothetical question}

Should regional development and entrepreneurial competitiveness on a limited market be seen as two sides of the same coin or as diverging processes? The Moroccan trekking tourism is a good example for the importance of efficient barriers to entry. In the trekking value chain the tour operators are holding a key function because they are the only ones to have direct access to the consumer market. For the Moroccan actors this access is only possible via co-operation with an associate partner in Europe. There are various barriers which make it impossible for them to operate directly in $\mathrm{Eu}-$ rope and this enables the tour operators to dominate the whole chain. They can do so, because the Moroccan companies who cover the biggest part of the market are all performing on a comparable high quality level. It seems to be a paradox situation that this turns out to be their greatest weakness. Organizational learning processes and experience knowledge enabled them to perform very professionaly in the field of tour planning and organization. But they are limited to this field of action. Further upgrading to fulfil the activities of a tour operator is not possible because of the existing barriers representing a bottleneck where a growing number of agencies are backing up, making it easier for the tour operators to change partners according to their conditions.

While direct access to the market for packaged tours appears to be blocked, access to the market for individual tourists seems to be, at least for the mountain guides, more promising. For trekkers who refuse to travel within an organized group, the hiring of the services of a mountain guide often is inevitable. Some of the guides have managed to do good business with individual trekkers, especially when they are recommended in internet trekking communities or in a traveller guide. But as the percentage of individual tourists in the Moroccan mountains is rather small while the number of (official and self-proclaimed) mountain guides is constantly rising, competition is getting fiercer. Thus, for those guides inside a network of trekking communities or travel guides, this may serve as a barrier to protect them on the individual market, but there is no barrier to stop the increasing competition for access to the package market. While the tour operators are quite good protected by several barriers, the Moroccan agencies haven't managed to do so. Even though there are barriers, these have proved to be fairly poor obstacles to overcome. The former assets of the pioneer companies have nowadays turned into ubiquitous know how and any agency may be replaced by another without great risk for the tour operator. It is a paradox situation that the common high standard of the Moroccan agencies have brought them into a situation in which the terms of trade are becoming increasingly worse for them precisely because of the fact that they all have adapted to the required international standards.

The spread of knowledge and information about international norms and standards and organizational know how throughout the Moroccan actors first evoked a desired development impact in the mountain regions and made them fit into the globally linked tourism business. The cooperation with a European partner offers Moroccan actors a possibility to have access to the European market. Governance and 
controlling, done by the European operators, aims to guarantee, that the Moroccan partners hold international standards and meet the tourists' expectation, so that the competitiveness of the entire chain is guaranteed. But the market for trekking in Morocco is not steadily growinging (especially not in times of generally tensed relations to the Islamic world), while the number of actors intending to enter these networks seems to be. The firstcomers among the Moroccan players have lost their competitive assets and this intensifies competition and weakens their position relative to the European tour-operators, who prevent a further advancement in the trekking chain. To evade into different activities is hardly possible for the Moroccan tourism actors who are bound to destinations inside Morocco. So while in industries (and especially in high-tech industries) learning processes and know how by experience are said to be a precondition for upgrading and innovation it seems as if in the special case of the Moroccan mountain tourism this has led to a reversal of what STORPER (1997) called a "widely accepted central element" of learning and technical innovation: Here it seems as if the pace of innovation is outrun by the forces of imitation. Further research is necessary to answer the hypothetical questions whether upgrading on the regional scale weakens the competitiveness on the firm level when direct market access is blocked and the branch is little innovative, and how institutional arrangements then have to be adapted to enable further upgrading.

\section{Note}

1 Especially in the relation with air companies they would face structural disadvantages. Because touroperators operate worldwide, their totality of flights exceeds those any Moroccan agency could mobilize. For that reason tour-operators can negotiate better prices and as a consequence offer better prices to their clients.

\section{References}

Ait Hamza, M., Popp, H. (2000): Trekking-Tourismus im Hohen Atlas. Beispiel für nachaltigen Tourismus in einer Peripherregion? In: Geographische Rundschau (52), 4-10.

Boujrouf, S. (1995): Tourisme et développement local - le cas de 1'expérience de Tabant. In : Royaume du Maroc, Ministère de 1'Intérieur, Ministère du Tourisme (Eds.) : Quel avenir pour le tourisme de montagne au Maroc? Actes du colloque international de Marrakech 18 - 21 Novembre 1995, n.p., 73-86.
Diaz BENAVIDES, D. (2002): Overcoming poverty in developing countries through self-sustainable international tourism. In: Rauschelbach, B./ Schäfer, A./Steck, B. (Eds.): Cooperating for sustainable tourism. Proceedings of the Forum International at the Reisepavillon 2002. Heidelberg, 9-28.

GerefFi, G./Memodovic, O. (2003): The global apparel value chain: What prospects for upgrading by developing countries? Vienna (United Nations Industrial Development Organization, UNIDO, Sectoral Studies Series).

Go, F.M./ Appelman, J. (2001): Achieving global competiteiveness in SMEs by building trust in interfirm alliences. In: Wahab, S./Cooper, Chr. (Eds).: Tourism in the age of globalisation. London, New York, 183-198.

HuMPhREY, J. (2003): Opportunities for SMEs in developing countries to upgrade in the global economy. Geneva. (International Labour Office, ILO, SEED Working Paper, 43).

IoAnnides, D./DebBage, K.G. (1998): The economic geography of the tourist industry: A supply side analysis. London.

KAPLINSKY, R./MorRIS, M. (2000): A handbook for value chain research. Brighton/Sussex. (Internetquelle: www.ids.ac.uk)

KEEGAN, W. (2002): Global marketing management. New Jersey.

LESSMEISTER, R. (2005): Organisationsstrukturen und Machtverteilung im marokkanischen Gebirgstourismus. n.p. (Diss., Internetquelle: http://opus.ub.uni-bayreuth.de/ volltexte/2006/199/pdf/Diss CD pdf. pdf).

Pauchant, E. (1995): Les différentes méthodes d'analyse des flux touristiques. In : Quel avenir pour le tourisme de montagne au Maroc? Actes du colloque international de Marrakech 18 - 21 Novembre 1995, ed. Royaume du Maroc, Ministère de 1'Intérieur, Ministère du Tourisme, n.p., 111-118.

Popp, H. (2004): Nachhaltiger Gebirgs- und Wüstentourismus in Südmarokko? In: Erdkunde, (58), 118136.

MÄDER, U. (1991): Vom Kolonialismus zum Tourismus - von der Freizeit zur Freiheit. Zürich.

REID, D.R. (2003): Tourism, globalization and development. Responsible tourism planning. London.

STORPER, M. (1997): The regional world: Territorial development in a global economy. New York, London.

VORLAUFER, K. 2003: Tourismus in Entwicklungsländern. Bedeutung, Auswirkungen, Tendenzen. In: Geographische Rundschau, (55), 4-14.

WAHAB, S./ COOPER, CHR. (Eds.) (2001): Tourism in the age of globalisation. London, New York.

YunIS, E. (2002): The International Year of Ecotourism: An opportunity to enhance marketing methods. In: Rauschelbach, B./Schäfer, A./Steck, B. (Eds.): Cooperating for sustainable tourism. Proceedings of the Forum International at the Reisepavillon 2002. Heidelberg, 33-37. 